\title{
Exchange Rate, Exchange Rate Volatility and Foreign Direct Investment in Sri Lanka ${ }^{1}$
}

\author{
S. G. S. D. Jayasekara*
}

\begin{abstract}
This paper investigates the effect of exchange rate, exchange rate volatility, and expected exchange rate on foreign direct investment and the factors, which are influential on exchange rate volatility in Sri Lanka during the period 1978-2012. Two equations were fitted and estimated using Zellner's seemingly unrelated regression model. Results of the equation 1 revealed that standard deviation of exchange rate, total electricity provision and trend were significant on foreign direct investment. According to the equation two, foreign direct investment, inflation and trade shocks were significant on exchange rate volatility during $1978-2012$ period. The results indicated that stability of exchange rate and improved infrastructure facilities were important to attract foreign direct investment.
\end{abstract}

Keywords: Exchange Rate; Exchange Rate Volatility; Expected Exchange Rate; Foreign Direct Investment

1. Views expressed in this paper are Author own and do not necessarily represent those of the Central Bank of the Sri Lanka.

* Senior Assistant Director at the Central Bank of Sri Lanka, e-mail: sisiradj@accamail.com 
Introduction

Studies on the exchange rate, exchange rate volatility, and Foreign Direct Investment (FDI) have generally focused on the hypotheses of (a) depreciation or devaluation of host country currency would encourage FDI inflows to the country; and (b) greater exchange rate volatility would discourage FDI inflows. Sri Lankan rupee has depreciated over the past few decades against major global currencies since the liberalization of Sri Lankan economy in 1977. Numerous studies have examined the effects of exchange rate on FDI (Froot \& Stein, 1991; Klein \& Rosengren, 1994; Bayoumi \& Lipworth, 1998; Goldberg \& Klein, 1998; Sazanami \& Wong, 1997; \& Sazanami et al., 2001). Only few studies have focused on the impact of exchange rate volatility on FDI. Findings of these studies are mixed. Some studies have found a positive impact of exchange rate volatility on FDI (Cushman, 1985 \& 1988; Goldberg \& Kolstad, 1995) and some others found a negative impact (Urata \& Kawai,2000; Benassy et al.,2001). Sazanami et al., (2001) reveals that there are at least two reasons for the mixed results concerning ambiguity in the impacts of exchange rate volatility on FDI. One possible reason is the use of aggregated national-level data without industry breakdown. Therefore, impacts of exchange rate on FDI differ among industries. The national-level data may result in the ambiguous results as such analysis masks impacts of exchange rate volatility among industries by offsetting the impacts across industries. Other possible reason is the lack of adequate treatment of exchange rate volatility. There are various studies done on FDI and the determinants of FDI in the aspect of economic growth of a country. However, the specific studies on FDI in terms of exchange rate related variables are limited and only few studies have been done in respect of Sri Lanka. The general objective of this study is to stress the Impact of exchange rate related variables on FDI. The specific objectives are to determine the effect of real exchange rate, standard deviation of monthly exchange rate, exchange rate volatility, expected exchange rate, infrastructure on the GDP share of FDI in Sri Lanka during 1978-2012 period; and to determine the effect of FDI, inflation, foreign reserves, and trade shocks on exchange rate volatility in Sri Lanka during 1978-2012 period. 
Figure 1: Depreciation of Sri Lankan Rupee Against US\$



Source: Compiled by the author based on data of Central Bank of Sri Lanka

Most of the existing literature supports the hypothesis that a depreciation of host country currency promotes FDI inflows (Harris \& Ravenscraft, 1991; Klein \& Rosengren, 1994; \& Dewenter, 1995). Studies, which looked at the impact of exchange rate on FDI flows in Sri Lanka, have also come to a similar conclusion (Jayasekara, 2011). However, there are contrary evidences (Stevens, 1998; Healy \& Palepu, 1993). Therefore, some ambiguity remains in the literature. Considering all, Pain and Van Welsum (2003) argued that the impact of exchange rate changes on FDI flows would differ across countries and types of investments.

\section{Exchange Rate Volatility and FDI}

The stability of a currency is an important factor for foreign investors since continuous fluctuations of exchange rates denote the currency instability of a country. Lower exchange rate in a host country means higher purchasing power of investing country's currency in host country. The relative change of real exchange rate in terms of LKR against US\$ is shown in Figure 2.

There are competing views of how exchange rate volatility affects FDI flows. One strand of the literature emphasizes the effect of risk aversion on foreign investors' desire to postpone investment decisions (Kohlhagen, 1977; Dixit, 1989). However, Campa (1993) showed that risk neutral investors could also display similar behav- 
ior. Another strand emphasized the adjustment costs of investment, especially the difficulty of reversing an investment decision once it is made (Dixit \& Pindyck, 1994). Although postponing investment will eliminate any expected profit stream from that investment, the ability to make choices that are more profitable in the future will be retained. Thus, the likelihood of delay in investment when faced with uncertainty is greater for industries in which the product life cycle is long, or for which the expected lifespan of firm-specific assets is long (Blonigen, 1997; Dunning, 1993).

Figure 2: Relative Change of Real Exchange Rate

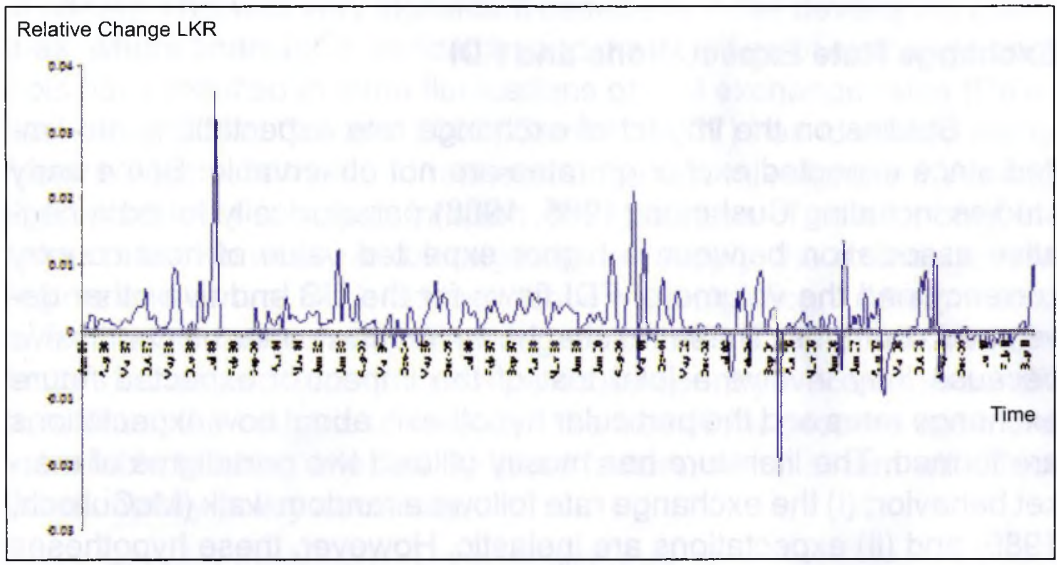

Source: Compiled by the author based on data of Central Bank of Sri Lanka

Another group of studies highlighted the difference between vertical and horizontal FDI. Vertical FDI, which involves the fragmentation of production processes across different countries, may be discouraged by exchange rate uncertainty because of the need to engage in intra-firm trade, whereas horizontal FDI, in which similar activities are undertaken in different locations, might even respond positively (Aizenman \& Marion, 2004). Crowley and Lee (2003) suggested that, if FDI involves some form of joint venture, reversibility will depend on whether any tacit knowledge has been transferred. Kiyota and Urata (2004) found that exchange rate volatility had discouraged Japanese FDI flows to a large number of countries during the period 1990-2000 for all types of industries.

However, there are some studies to suggest that exchange rate volatility actually promoted FDI flows. Itagaki (1981) and Cushman (1985) suggested cases in which uncertainty could theoretically 
increase FDI if it is used as a substitute for exports. Goldberg and Kolstad (1995) suggested that greater short-run real exchange rate volatility will raise the share of foreign production in total production. Lin et al. (2010) examined how exchange rate uncertainty influences the timing of FDI using firm-level data on Taiwanese firms' outward FDI into China over the period between 1987 and 2002. They concluded that exchange rate uncertainty tends to delay the FDI activity of a market-seeking firm and, it may accelerate the FDI activity of an export-substituting firm if the degree of risk aversion of the firm is high enough.

\section{Exchange Rate Expectations and FDI}

Studies on the impact of exchange rate expectations are limited since expected exchange rates are not observable. Some early studies including Cushman $(1985,1988)$ paradoxically found a negative association between a higher expected value of host country currency and the volume of FDI flows for the US and five other developed countries. These results, however, can never be conclusive because they involve a joint test of the impact of expected future exchange rates and the particular hypothesis about how expectations are formed. The literature has mostly utilized two paradigms of market behavior: (i) the exchange rate follows a random walk (McCulloch, 1989) and (ii) expectations are inelastic. However, these hypotheses have different implications. Under the random walk assumption, expectations are perfectly elastic to the current exchange rate, so that they do not affect FDI. However, Frankel and Froot (1987) found evidence that expected future spot rates are inelastic to the current spot rate, namely: economic agents do not update their expectations of the future exchange rate up to the current level. Takagi (2011), based on his review of survey data studies, concluded that depreciation tends to be followed by expectations of further depreciation in the short run but by expectations of moderate reversal (or appreciation) in the long run, and that the tendency for mean reversion increases during periods of sharp volatility. Economic agents may be reacting differently to small and large exchange rate shocks when updating their exchange rate expectations (Chakrabarti \& Scholnick, 2002). Despite the relatively limited literature on exchange rate expectations, Jongen et al., 2008 suggested the importance of exchange rate expectations for portfolio and other economic decisions. Pain et al., (2003) attempted to link this with FDI flows but it was rather limited. Udomkerdmongkol 
et al., (2009) may well be among the very few that have introduced exchange rate expectations in an analysis of FDI flows from a developed to emerging market economies.

\section{Determinants of Exchange Rate Volatility}

Since the collapse of Bretton Woods in 1973 and the switch to floating exchange rates, the volatility of the Real Exchange Rate (RER) has increased, with significant effects on economic growth, capital movements and international trade (Baig, 2001; Hviding et al.,2004). This was very significant especially in the developing countries, where financial liberalization and the abolition of exchange controls have resulted in large fluctuations of real exchange rates (Reinhart et al., 2002; Corden, 2002). Stancik (2007) has identified many factors, which contribute to real exchange rate misalignment. Among those, the level of output, inflation, the openness of an economy, interest rates, domestic and foreign money supply, the exchange rate regime and central bank independence were significant determinants of exchange rate volatility. The degree of the impact of each of the factors varies and depends on a particular country's economic condition. Thus, the countries that are in the transitions process are more vulnerable to being affected by these factors, which in turn will affect the monetary policy decisions.

These important topics are still in debate among researchers. Juthathip (2009) showed that the real exchange rate is determined by five key fundamental variables that are medium to long-run fundamentals: productivity differentials, openness, terms of trade, net foreign assets and government spending other variables such as output gap may be included in some countries where such factors play an important role in determining the real exchange rate.

Gorgea et al., (2008) introduced a good survey of the literature about the determinants of the real exchange rate, where they determined the factors that drive the real exchange rate in the long run. The Balassa Samuelson effect, government spending, the terms of trade, the openness degree, foreign capital flows were added as determinants, of the de facto nominal exchange rate regime, which can potentially impact the real exchange rate. Clark and MacDonald (1998) found that the equilibrium real exchange rate is determined as a function of both the vector of long-run economic fundamentals and the interest rate differential. 
Analysis of the literature on FDI and exchange rates reveals that there is not a single theory that explains the impact of exchange rate related variables on FDI. However, a variety of theoretical models have been used to explain impacts on FDI. The literature is not only extensive but it is also controversial as well. The following research hypotheses are formed based on the literature review for the purpose of empirical analysis.

Table 1: Research Hypotheses

\begin{tabular}{lllc}
\hline $\begin{array}{c}\text { Endogenous } \\
\text { Variable }\end{array}$ & Exogenous Variable & $\begin{array}{c}\text { Expected } \\
\text { Relationship }\end{array}$ & Equation \\
\hline Foreign & $\begin{array}{l}\text { Real Exchange Rate } \\
\text { Direct }\end{array}$ & Negative & 7 \\
Investment & Mondard Deviation of & Negative & 7 \\
& Rate & Neal Exchange & 7 \\
& Exchange Rate Volatility & Negative & 7 \\
& Total Electricity Provision & Positive & 7 \\
& Expected Exchange Rate & Negative & 7 \\
Exchange & Foreign Direct Investment & Positive & 8 \\
Rate Volatility & Inflation & Positive & 8 \\
& Foreign Reserves & Positive & 8 \\
& Trade Shocks & Positive & 8 \\
\hline
\end{tabular}

\section{Methodology}

This study is primarily based on the secondary time series data from year1978 to 2012. Data for the Inflow of FDI was obtained from the Stat database compiled by the United Nations Conference on Trade and Development (UNCTAD) and data for other variables was obtained from the Central Bank of Sri Lanka and the World Development indicators database compiled by the World Bank. Many previous studies on this area have used Multivariate Regression Analysis (MRA) (Kriljenko et al., 2004: Lin et a., 2010). In MRA, it is required the design matrix for each of $p$ dependent variables to be the same as in its form and assumed that all the coefficients in the model are unknown and estimated from the data. In contrast, this paper uses Zellner's Seemingly Unrelated Regression (SUR) model, which has been developed as $p$ correlated regression equations. It allows each of the $p$ dependent variables to have a different design matrix with some of the predictor variables being the same It allows variables to be in both the $\mathrm{Y}$ and $\mathrm{X}$ matrices. 
As explained above. MRA requires that the design matrix for each of $p$ dependent variables to be exactly the same in its functional form as below.

$$
Y_{(\mathrm{N} \times \mathrm{p})}=X_{(\mathrm{N} \times \mathrm{k})} \mathrm{B}_{(\mathrm{kxp})}+\mathrm{e}_{(\mathrm{N} \times \mathrm{p})}
$$

Where: $Y$ is a matrix of $p$ dependent variables, $X$ is a k-dimensional design matrix, and $\mathrm{e}$ is an error matrix, which is assumed to be distributed as $N_{(\mathrm{Nxp})}\left(0, \Sigma \oplus \oplus I_{N}\right)$. Multivariate regression theory using Ordinary Least Squares (OLS) assumes that all of B coefficients in the model are unknown and to be estimated from the data as:

$$
\widehat{B} \hat{B}=\left(X^{\prime} X\right)^{-1} X^{\prime} Y \text {. }
$$

According to Zellner (1962), the $p$ regression equations are "seemingly unrelated" because separately taken error terms would follow standard linear OLS linear model form. However, standard OLS solutions ignore any correlation among the errors across equations but the dependent variables are correlated and the design matrices may contain some of the same variables and there may be "contemporaneous "correlation among the errors across the $p$ equations.

Thus, SUR models are often applied when there may be several equations, which appear to be unrelated; however, they may be related by the fact that: (1) some coefficients are the same or assumed to be zero; (2) the disturbances are correlated across equations; and/or (3) a subset of right hand side variables are the same. This third condition is of particular interest because it allows each of the $p$ dependent variables to have a different design matrix with some of the predictor variables being the same. In fact, SUR models allow for a variable to be both in the $\mathbf{Y}$ and $\mathbf{X}$ matrices, which has particular relevance to path analysis.

SUR model is a generalisation of multivariate regression using a vectorized parameter model. The $Y$ matrix is vectorized and vertically concatenated, $y_{v}$. The design matrix, $\mathrm{D}$, is formed as a block diagonal with the $\mathrm{j}^{\text {th }}$ design matrix, $\mathrm{X}_{j}$, is on the $\mathrm{j} \mathrm{j}^{\text {th }}$ block of the matrix. The model is then expressed as :

$$
\begin{aligned}
& E\left[Y_{(N \times p)}=\left\{X_{1}\left(N x m_{1}\right) \beta_{1}\left(m_{1} \times 1\right), X_{2}\left(N x m_{2}\right) \beta_{2}\left(m_{2} \times 1\right), X_{j}\left(N x m_{j}\right) \beta_{j}\left(m_{j} \times-\right.\right.\right. \\
& \left.1), X_{p}\left(N x m_{p}\right) \beta_{p}\left(m_{p} \times 1\right)\right\} ;
\end{aligned}
$$


Where $m_{i}$ is the number of parameters estimated (3) $\mathrm{umns}$ by the $\mathrm{j}^{\text {th }}$ design matrix, $\mathrm{X}_{\mathrm{j}}$. This model can be illustrated as follows.

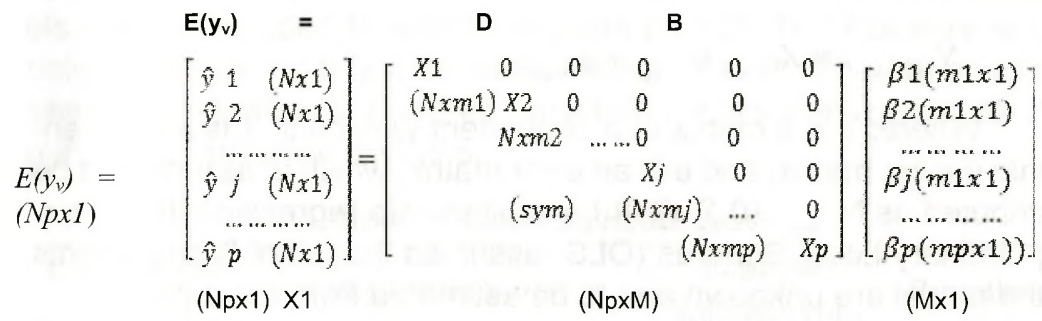

Where $M$ is the total number of parameters estimated over the $p$ models, $M=\sum_{j=1}^{p} m_{\mathrm{j}} M=\sum_{j=1}^{p} m$. The parameter estimates are solved as

$$
\hat{B} \quad=\left[\underset{(M x N p)}{D^{\prime}} \underset{(N p x N p)(N p x M)}{Q^{-1}} \underset{(M x N p)}{D} \underset{(N p x N p)}{Q^{-1}} \underset{(N p x 1)}{D}\right]
$$

$Q$ is weight matrix based on the residual covariance matrix of the $Y$ variables and is formed as :

$$
\begin{aligned}
& \text { as : } \underset{(N p x N p)}{Q}=\sum_{(p x p)} \oplus I_{N} \text {. The i i th }{ }^{\text {th }} \text { element of } \hat{\sum} \text { is calculated as: } \\
& \widehat{\sigma}_{i j}=\frac{1}{(N-d f *)^{2}}, \tilde{\mathbb{N}}_{N} \tilde{O} \mathrm{H}_{\mathrm{j}}\left[\mathrm{I} I_{N} \tilde{O} \mathrm{H}_{j}\right] \mathrm{y}_{\mathrm{j}}
\end{aligned}
$$

Where $H_{j}=X_{j}\left(X_{j}^{\prime} X_{j}\right)^{-1} X_{j}^{\prime}$ is the hat matrix for the $j^{\text {th }}$ design matrix and $\mathrm{df}^{\star}$ is the average of the numerator degrees -of-freedom (df) for the $\mathrm{i}^{\text {th }}$ and $\mathrm{j}^{\text {th }}$ models.

According to the above SUR model, the following two equations were fitted in linear form.

$\left(F D I_{t} / G D P_{t}\right)=f\left(R R_{t}, E_{t}, V_{t}, I_{t}\right.$ NFR $\left._{t}, E R_{t}\right)$

$$
\text { VOL }_{\mathrm{t}} \quad=f\left(\text { FDI }_{\mathrm{t}, \mathrm{I}} \text { INF }_{\mathrm{t}}, \mathrm{RES}_{\mathrm{t}}, \text { TOT }_{\mathrm{t}}\right)
$$

Description, definition and measurement of data are given at the Table 2. 
Table 2: Description, Definition, and Measurement of Variables

\begin{tabular}{|c|c|c|}
\hline Variable & Description & Definition and Measurement \\
\hline FDI & $\begin{array}{l}\text { Inward } \\
\text { Foreign Direct } \\
\text { Investment }\end{array}$ & $\begin{array}{l}\text { Foreign direct investment is defined } \\
\text { as an investment involving a long-term } \\
\text { relationship and reflecting a lasting interest } \\
\text { of a resident entity in one economy in an } \\
\text { entity resident in an economy other than } \\
\text { that of the investor. FDI is measured as the } \\
\text { inward foreign direct investment flows in } \\
\text { terms of US\$ at current prices. }\end{array}$ \\
\hline GDP & $\begin{array}{l}\text { Gross Domestic } \\
\text { Product }\end{array}$ & $\begin{array}{l}\text { The monetary value of all the finished } \\
\text { goods and services produced within } \\
\text { a country's borders in a year. GDP is } \\
\text { measured in terms of US } \$ \text { at current prices }\end{array}$ \\
\hline RER & $\begin{array}{l}\text { Real Exchange } \\
\text { Rate }\end{array}$ & $\begin{array}{l}\text { Real exchange rate is the purchasing } \\
\text { power of a currency relative to another at } \\
\text { current exchange rates and prices. It is } \\
\text { measured as follows. } \\
F E R=e\left(\frac{P}{\text { Where : }}\right. \\
\mathrm{e} \text { - price of one unit of a foreign currency } \\
\text { in units of domestic currency(nominal } \\
\text { exchange rate), } \\
\mathrm{p}^{*} \text { - foreign price level, and } \\
\mathrm{p} \text { - domestic price level. }\end{array}$ \\
\hline EXD & $\begin{array}{l}\text { Standard } \\
\text { Deviation of } \\
\text { Exchange Rate }\end{array}$ & $\begin{array}{l}\sigma=\sqrt{\mathrm{E}\left[(X-\mu)^{2}\right]}=\sqrt{\mathrm{E}\left[X^{2}\right]-(\mathrm{E}[X])^{2}} \\
\text { Where: } \\
X \text { - Annual Exchange Rate; } \\
\mu \text { - Mean of annual exchange rate; }\end{array}$ \\
\hline RES & $\begin{array}{l}\text { Foreign } \\
\text { Reserves }\end{array}$ & $\begin{array}{l}\text { Foreign reserves are assets held by central } \\
\text { banks and monetary authorities, usually in } \\
\text { different reserve currencies and used to } \\
\text { back its liabilities. It is measured in terms } \\
\text { of US } \$ \text { at current prices. Cont.. }\end{array}$ \\
\hline
\end{tabular}




\begin{tabular}{|c|c|c|}
\hline INFR & Infrastructure & $\begin{array}{l}\text { The basic physical and organizational } \\
\text { structures and facilities needed for the } \\
\text { operation of a society or enterprise: The } \\
\text { total electricity provision of the country } \\
\text { is used as a proxy to measure the } \\
\text { infrastructure quality of the country. }\end{array}$ \\
\hline EER & $\begin{array}{l}\text { Expected } \\
\text { Exchange Rate }\end{array}$ & $\begin{array}{l}\text { Expected exchange rate }(\$: L K R)=\mathrm{e} \\
(1+\mathrm{rLK}) /(1+\mathrm{rUS}) \\
\text { Where: e - Nominal exchange rate; } \\
\text { rLK - Interest rate in Sri Lanka; } \\
\text { rUS - Interest rate in the United States of } \\
\text { America }\end{array}$ \\
\hline INF & Inflation & $\begin{array}{l}\text { The rate of inflation is the percentage } \\
\text { change in the price level in a given period. } \\
\text { Increase in general price level is often } \\
\text { measured by an index of consumer prices. } \\
\text { For the purpose of this study, inflation is } \\
\text { measured based on the changes in the } \\
\text { consumer price index. }\end{array}$ \\
\hline TOT & Trade Shocks & $\begin{array}{l}\text { Trade balance is the difference between } \\
\text { the value of exports and imports of goods } \\
\text { and services over a period of one year. } \\
\text { The trend of the trade balance is used as } \\
\text { a proxy to trade shocks. }\end{array}$ \\
\hline
\end{tabular}

\section{Findings}

Unit root test for variables was performed to assess the stationary of variables prior to the estimation. The result of the unit root test is summarised in table 3 . The results of the unit root test reveal that all the variables are stationary at first difference. 
Table 3: Stationary (Unit Root) Test for Variables

\begin{tabular}{lccl}
\hline Variable & $\begin{array}{c}\text { ADF }{ }^{1} \text { t- } \\
\text { Statistics }\end{array}$ & Probability & Decision \\
\hline Fdi/Gdp & -8.120645 & 0.0000 & Stationary at 1 ${ }^{\text {st }}$ difference \\
Rer & -7.535681 & 0.0000 & Stationary at 1st difference \\
Exdt & -6.896849 & 0.0000 & Stationary at 1st difference \\
Vol & -7.490546 & 0.0000 & Stationary at 1st difference \\
Infr & -13.11606 & 0.0000 & Stationary at 1st difference \\
Eer & -7.482678 & 0.0000 & Stationary at 1st difference \\
Inf & -7.995457 & 0.0000 & Stationary at 1st difference \\
Res & -12.00416 & 0.0000 & Stationary at 1st difference \\
Tot & -12.69877 & 0.0000 & Stationary at 1st difference \\
\hline
\end{tabular}

Source: Compiled by the author based on the secondary data

The $R^{2}$ of 0.467 shows that nearly $47 \%$ of the variation of the FDI is shown by the variables fitted in the equation. The Durbin-Watson statistic is inclusive indicating their auto-regression may not be a factor to be considered.

Table 4: Regression Coefficients for FDI Equation Endogenous Variable: FDI/GDP

\begin{tabular}{|c|c|c|c|c|}
\hline $\begin{array}{c}\text { Exogenous } \\
\text { Variable }\end{array}$ & $\begin{array}{l}\text { Parameter } \\
\text { Estimate }\end{array}$ & $\begin{array}{l}\text { Standard } \\
\text { Error }\end{array}$ & $\mathrm{t}$ - Value & Significance \\
\hline Intercept & 16387.67 & 13888.82 & 1.18 & NS \\
\hline Rer & -1.8862 & 1.78337 & -1.05 & NS \\
\hline Exdt & -6.23144 & 3.5114 & -1.77 & ** \\
\hline Vol & -476789 & 33911 & -1.4 & NS \\
\hline Infr & -0.9288 & 0.48761 & -1.9 & * \\
\hline Eer & 3.537 & 4.9041 & -0.72 & NS \\
\hline Year & -7.75494 & 3.4338 & -2.25 & * \\
\hline
\end{tabular}

Source: Compiled by the author based on secondary data 
FDI does not hold a statistically significant relationship with real exchange rate, exchange rate volatility, and expected exchange rate as hypothesized. However, some previous studies have confirmed statistically significant relationship of FDI with real exchange rate (Froot \& Stein, 1991; Jayasekara, 2011). Further, there were contrary evidences as well (Stevens, 1998; Healy \& Palepu, 1993). Therefore, some ambiguity remains in the literature. Considering all, Pain and Van Welsum (2003) argued that the impact of exchange rate changes on FDI flows would differ across countries and types of investment.

Hypothesis of negative relationship of FDI with exchange rate volatility has been confirmed by many previous studies (Kohlhagen, 1977; Dixit, 1989; Campa, 1993; Dixit \& Pindyck, 1994; Blonigen, 1997; Dunning, 1993; Aizenman \& Marion, 2004; \& Crowley \& Lee, 2003). However, there are some studies to suggest that exchange rate volatility actually promotes FDI flows. Itagaki, (1981) and Cushman (1985) suggested cases in which uncertainty could theoretically increase FDI if it is used as a substitute for exports. Goldberg and Kolstad (1995) suggested that greater short-run real exchange rate volatility would raise the share of foreign production in total production. However, the standard deviation of exchange rate shows a statistically significant negative relationship with FDI.

Expected exchange rate shows a positive relationship but the relationship is not statistically significant. Studies on the impact of exchange rate expectations are limited since expected exchange rates are not observable. Some early studies including Cushman (1985, 1988) paradoxically found a negative association between a higher expected value of host country currency and the volume of FDI flows for the US and five other developed countries. These results, however, can never be conclusive because they involve a joint test of the impact of expected future exchange rates and the particular hypothesis about how expectations are formed. However, Frankel and Froot (1987) found evidence that expected future spot rates are inelastic to the current spot rate, namely: economic agents do not update their expectations of the future exchange rate up to the current level. Takagi (1991), based on his review of survey data studies, concluded that depreciation tends to be followed by expectations of further depreciation in the short run but by expectations of moderate reversal in the long run, and that the tendency for mean reversion increases during periods of sharp volatility. Udomkerdmongkol et al (2009) may well be among the very few that have introduced exchange rate expectations in an analysis of FDI flows from a developed to emerging market. 
Quality of infrastructure is an important determinant of FDI when developing countries compete for FDI. The country that is best prepared to address infrastructure bottlenecks will secure a greater amount of FDI. Different studies have used different variables as a proxy to measure Infrastructure quality since it is a broad concept. Mohamed et al.,(2010) have used the number of telephone lines per 1000 people to measure the infrastructure quality. A higher value implies greater productive efficiency and thus greater returns. Therefore, it was hypothesized that total electricity provision has a positive relationship with foreign direct investment. The literature on infrastructure quality in FDI shows a positive impact on FDI inflows (Wheeler \& Mody, 1992; Asiedu, 2002 \& Mohamed et al.,2010).

This study revealed a negative statistically significant relationship of the trend of foreign direct investment. This result shows that FDI has been declining generally over the period of study.

Table 5: Regression Coefficients for Exchange Rate Volatility Endogenous Variable: Exchange Rate Volatility

\begin{tabular}{lrrrc}
\hline $\begin{array}{l}\text { Exogenous } \\
\text { Variables }\end{array}$ & $\begin{array}{r}\text { Parameter } \\
\text { Estimate }\end{array}$ & Standard Error & $t$ - Value & Significance \\
\hline $\begin{array}{l}\text { Intercept } \\
\text { Fdi }\end{array}$ & $\begin{array}{r}0.0002 \\
\text {-0.000000135 }\end{array}$ & 0.000000067 & -2.03 & * \\
& & & & \\
Inf & 0.000001963 & 0.000000961 & 2.04 & $*$ \\
& 0.000000086 & 0.000000086 & 1.00 & NS \\
Res & 0.00001 & 0.000008038 & 2.18 & $*$ \\
Tot & -0.000000106 & 0.000000492 & -0.22 & NS \\
Year & & & & \\
\hline
\end{tabular}

Notes: $R S Q=0.667 \quad D, W=1.91 *=$ Significant at $5 \%$ level $\quad N S=$ Not significant

Source: Compiled by the author based on secondary data

The results of equation 8 showed that nearly $67 \%$ of the variation of exchange rate volatility shown by the exogenous variables used in the model. Durbin-Watson statistic is inconclusive relating to the auto-regression. 
FDI shows a statistically significant negative relationship on exchange rate volatility. The negative sign of the FDI may be due to the lower foreign investments available in the economy over the period 1978-2012. Generally, capital inflows are accompanied by real exchange rate appreciation in the economy (Corden, 1994). Capital inflows cause increases in consumption demand for both traded and non-traded goods, which in turn leads to a rise in the price of non-traded goods to regain the equilibrium of the market. The increase in traded consumptions causes the trade balance to deteriorate without any changes in the price of traded goods. More advanced studies (Athukorala \& Rajapatirana, 2003) have shown that the impact of capital flows depends mainly on both the composition of capital flows (FDI or portfolio inflows) and on differences in the degree of response of the RER to capital flows.

RER appreciation is a phenomenon mostly more associated with portfolio investments than with FDI. While portfolio investments are speculative capital flight looking for higher short-term yields and can be a source of instability, FDI flows are related to investment in imports of new machinery and equipment and thus create almost no appreciation effect (Jean-Louis, 2009). The spillover effects of FDI may improve local productivity through the transfer of technology and managerial know-how. According to the future improvements of productivity, Saborowski (2009) suggested that the exchange rate appreciation effect of FDI inflows is indeed attenuated when financial and capital markets are larger and more active. FDI therefore lead to RER appreciation in developing countries. However, Kriljenko and Habermeier, (2004) found that private capital flows including FDI relative to GDP was not significantly correlated with exchange rate volatility.

Inflation shows a statistically significant positive relationship with exchange rate volatility. This has been confirmed by many studies. Kriljenko and Habermeier, (2004) having studied the factors affecting exchange rate volatility based on a broad cross section of 85 developing and transition economies in 2001 concluded that exchange rate volatility was higher in countries with higher inflation and higher fiscal deficits, and lower in countries with faster real GDP growth and more open economies.

In contrast, there is a wide consensus in the literature that the Purchasing Power Parity (PPP) is not an appropriate model for the determination the Equilibrium Real Exchange Rate (ERER) because 
of the slow convergence of the Real Exchange Rate (RER) with the long-run equilibrium level (MacDonald \& Ricci, 2003). The PPP theory predicts that price levels are equalized when measured in the same currency, which suggests that the real equilibrium exchange rate should be constant and equal to unity. However, empirical work on testing PPP is not very supportive of the theory.

Foreign reserves show a positive relationship with exchange rate volatility and it is not statistically significant. An increase in the net foreign assets will lead to an appreciation of the real exchange rate following from a rise in domestic demand and an increase in non-tradable prices. In this respect, other factors that affect the volatility of the real exchange rate, such as Central Bank Independence are associated with lower inflation and more price stability (Christopher \& Ellen 2008), and the exchange rate regime. Kriljenko and Habermeier (2004) found that foreign exchange reserves were not strongly correlated with exchange rate volatility. Reserves were not found to be statistically significant, whether measured relative to the money base, short-term debt owed to the countries reporting to Bank for International Settlements, imports of goods, or GDP; however, higher reserves correlated negatively with exchange rate volatility. Countries satisfying the "currency board criteria," with international reserves exceeding the money base at the prevailing exchange rate, did not have a statistically significant lower level of exchange rate volatility.

Trade shocks show a statistically significant positive relationship with exchange rate volatility. Prevailing literature has mainly considered the international trade instead of trade shocks. Some studies have found that the volatility of the real exchange rate has increased, with significant effects on economic growth, capital movements and international trade (Baig,2001 and Hviding et al., 2004). However, Kriljenko and Habermeier, (2004) revealed that the current account deficit and the volatility of the terms of trade were not found to be significantly correlated with exchange rate volatility.

This study revealed a negative relationship of the trend of exchange rate volatility showing a declining trend of exchange rate volatility over the period of study. 


\section{Conclusion}

Main objectives of this study were to determine the effect of real exchange rate, standard deviation of monthly exchange rate, exchange rate volatility, expected exchange rate and infrastructure on the GDP share of FDI and to determine the effect of FDI, inflation, foreign reserves, trade shocks on exchange rate volatility in Sri Lanka during the period 1978-2012. This study used Zellner's seemingly unrelated Regression model to estimate the FDI and exchange rate volatility equations. The results suggested that FDI has statistically significant relationship with standard deviation of exchange rate, total electricity provision and year. Further, exchange rate volatility has statistically significant relationship with foreign direct investment, inflation and trade shocks over the period of study. Therefore, stability of exchange rate is vital for foreign direct investments as well as to the economic stability of the country. Empirical results suggested that FDI is significantly correlated with the exchange rate volatility. Therefore, monetary and fiscal policy measures are required to reduce budget deficit, trade gap and debt ratios in order to maintain a stable exchange rate. Further, the infrastructure quality showed a statistically significant negative relationship with FDI instead of a positive relationship. Therefore, it is assumed that prevailing infrastructure quality does not meet the expectations of foreign investors. Policy measures are required to improve the quality of basic infrastructure facilities such as electricity, water, transportation and telecommunication.

\section{References}

Aizenman, J., \& Marion, N. (2004). The merits of horizontal versus vertical $\mathrm{FDI}$ in the presence of uncertainty. Journal of International Economics, $62,125-148$.

Athukorala,P.C., \& Rajapatirana,S.(2003). Capital inflows and the real exchange rate: $A$ comparative study of Asia and Latin America. The World Economy, 26, 613-637.

Baig, T. (2001). Characterizing exchange rate regimes in post-crisis East Asia. Working Paper WP/01/152. Washington, DC: International Monetary Fund.

Bayoumi,T., \& Gabrielle, L.(1998). Japanese foreign direct investment and regional trade. Joumal of Asian Economics, 9 (4), 581-607. 
Blonigen, B.A. (1997). Firm-specific assets and the link between exchange rates and foreign direct investment. American Economic Review, $87,447-465$.

Buch, C.M., \& Kleinert, J. (2008). Exchange rates and FDI: Goods versus capital markets frictions. The World Economy, 31, 1185-1207.

Campa, J.M. (1993). Entry by foreign firms in the United States under exchange rate uncertainty. Review of Economics and Statistics, 75, 614-622.

Chakrabarti, R., \& Scholnick,B.(2002). Exchange rate expectations and foreign direct investment flows. Weltwirtschaftliches Archive, 138, $1-21$.

Clark, P. B., \& MacDonald,R.(1998). Exchange rates and economic fundamentals: A methodological comparison of BEERs and FEERs. IMF Working Paper WP/98/67. Washington, DC: International Monetary Fund.

Corden, W. M. (2002). Too sensational: On the choice of exchange rate regimes. Cambridge: MIT Press. Crowley, P., \& Lee, J. (2003). Exchange rate volatility and foreign investment: International evidence. The Intemational Trade Journal, 7, 227-252.

Cushman, D.O. (1985). Real exchange rate risk, expectations, and the level of direct investment. Review of Economics and Statistics, 67, 297-308.

Cushman, D.O. (1988). Exchange-rate uncertainty and foreign direct investment in the United States. Review of World Economics, 124, 322-336.

Dewenter, K.L. (1995). Do exchange rate changes drive foreign direct investment?. Joumal of Business, 68, 405-433.

Dixit, A. (1989). Entry and exit decisions under uncertainty. Journal of Political Economy, 97, 620-638.

Dixit, A., \& Pindyck, R.S. (1994). Investment under uncertainty. Princeton, NJ: Princeton University Press.

Dunning, J.H. (1993). Multinational enterprises and the global economy. Massachusetts :Addison-Wesley, Reading.

Frankel, J.A., \& Froot, K..A. (1987). Using survey data to test standard propositions regarding exchange rate expectations. American Economic Review, 77,133-153. 
Froot, K. A., \& Stein,J.C. (1991). Exchange rates and foreign direct investment: An imperfect capital markets Approach. Quarterly Joumal of Economics, 106 (4), 1191-1217.

Goldberg, L.S., \& Kolstad, C.D. (1995). Foreign direct investment, exchange rate variability, and demand uncertainty. Intemational Economic Review, 36, 855-873.

Goldberg,L.S., \& Michael,K. (1998). Foreign direct investment, trade, and real exchange rate linkages in developing countries, In Reuven Glick (Ed). Managing capital flows and exchange rates: Perspectives from the Pacific Basin, Cambridge, UK: Cambridge.

Gujarati D. N. (2009). Basic econometrics. New Delhi. McGraw-Hill Higher Education.

Harris, R.S., \& Ravenscraft, D. (1991). The role of acquisitions in foreign direct investment: Evidence from the U.S. stock market. Joumal of Finance, 46, 825-844.

Healy, P., \& Palepu, K.G. (1993). International equity acquisitions: Who, where and why?, In K.A. Froot (Ed.) Foreign direct investment. (pp 231-253). Chicago: University of Chicago Press.

Hviding K., Nowak ,M., \& Luca, A. R. (2004). Can higher reserves help reduce exchange rate volatility?. IMF Working Paper WP/04/189, I Washington, DC: International Monetary Fund.

Itagaki,T.(1981).The theory of the multinational firm under exchange rate uncertainty. Canadian Journal of Economics, 14, 276-297.

Jayasekara, S. G .S. D. (2011). Determinant of foreign direct investment in Sri Lanka, (Unpublished master thesis University of Birmingham.)

Jongen, R.,Verschoor, W.F.C., \& Wolff,C.C.P. (2008). Foreign exchange rate expectations: Survey and synthesis. Joumal of Economic Surveys, $22,140-165$

Juthathip, J. (2009). Equilibrium real exchange rate misalignment and export performance in developing Asia, ADB Economics, WP, No 151. Momila.

Kiyota, K., \& Urata, S. (2004). Exchange rate, exchange rate volatility and foreign direct investment. The World Economy, 27, 1501-1536.

Klein, M.W., \& Rosengren,E. (1994). The real exchange rate and foreign direct investment in the United States: Relative wealth vs. relative wage effects. Joumal of Intemational Economics, 36 (3/4), 373-389. 
Kohlhagen, S.W. (1977). Exchange rates, profitability, and direct foreign investment. Southern Economic Joumal, 68, 43-52.

Kriljenko,J.C ., \& Habermeier, K.(2004). Structural factors affecting exchange rate volatility: A cross-section study. IMF Working Paper WP/04/147, Washington, DC: International Monetary Fund.

Lin, C.C., Chen, K.M., \& Rau, H.H. (2010). Exchange rate volatility and the timing of foreign direct investment: Market-seeking versus export-substituting. Review of Development Economics, 14 (3), 466486.

Pain, N., \& Van Welsum, D. (2003). Untying the Gordian knot: The multiple links between exchange rates and foreign direct investment. Journal of Common Market Studies, 41, 823-846.

Quere,B., Lionel, F., \& Revil,A.L. (2001). Exchange rate strategies in the competition for attracting foreign direct investment. Journal of the Japanese and Intemational Economies, 15 (2), 178-198.

Reinhart, C. M., \& Todd,S.R.(2001). Temporary controls on capital inflows. Joumal of Intemational Economics, 57, 327-351

Sazanami, S.Y., \& Kozo, K. (2001 September 26-27). Japanese foreign direct investment flows to East Asia and the real exchange rate: Lessons from the Asian financial crisis. Conference proceedings: Regional development and the global economy, European and East Asian experience, University of Le Havre, Le Havre, France.

Stancik, J. (2007). Determinants of exchange rate volatility: The case of the new EU members. Czech joumal of economics and finance, 57, 9-18.

Stevens, G.V.G. (1998). Exchange rates and foreign direct investment: A note. Journal of Policy Modeling, 20, 393-401.

Takagi, S., \& Shi, Z. (2011). Exchange rates movements and foreign direct investment: Japanese investment in Asia, 1987-2008. Japan and World Economy, 746, 1-8.

Udomkerdmongkol, M., Morrissey, O., \& Gorg, H. (2009).Exchange rates and outward foreign direct investment: US FDI in emerging economies. Review of Development Economics, 13, 754-764. 
96 Sri Lanka Journal of Advanced Social Studies Vol. 3 - No. 2 - July-December -2013

Urata,S., \& Hiroki, K. (2000). The determinants of the location of foreign direct investment by Japanese small and medium-sized enterprises. Small Business Economics, 15 (2), 79-103.

Zellner, A. (1962). An efficient method of estimating seemingly unrelated regressions and tests for aggregation bias. Joumal of the American Statistical Association, 57,348-368. 